\title{
Intra-Axial Metastatic Angiosarcoma of the Central Nervous System Associated with Anemia, Pulmonary Tuberculosis and Short Survival
}

\section{Angiossarcoma metastático intra-axial do sistema nervoso central associado a anemia, tuberculose pulmonar e sobrevivência curta}

\author{
Eduardo Cambruzzi ${ }^{1,2,3,4,5}$ Júlia Rispoli dos Santos 4 (두 \\ William Pegoraro Kus ${ }^{60}$ Felipe Lourezon Schiavo ${ }^{6(0)}$

\footnotetext{
${ }^{1}$ Department of Histology and Pathology, Universidade Federal do Rio Grande do Sul, Porto Alegre, RS, Brazil

2 Department of Pathology, Complexo Hospitalar Santa Casa, Hospital Santa Rita, Porto Alegre, RS, Brazil

${ }^{3}$ Hospital N. Sra. da Conceição, Porto Alegre, RS, Brazil

${ }^{4}$ Universidade Luterana do Brasil, Canoas, RS, Brazil

${ }^{5}$ Instituto de Cardiologia, Fundação Universitária de Cardiologia,

Porto Alegre, RS, Brazil

${ }^{6}$ Department of Pathology, Hospital N. Sra. da Conceição, Porto

Alegre, RS, Brazil
}

Karla Lais Pêgas ${ }^{2,3(1)}$ William Mazzuco Nesi60 Samir Cezimbra dos Santos 6 (1)

Arq Bras Neurocir 2020;39(3):222-227.

\begin{abstract}
Address for correspondence Eduardo Cambruzzi, MD, PhD, Pathologist, Neuropathologist, Professor of Pathology, Departmento de Patologia Complexo Hospitalar Santa Casa, Hospital Santa Rita, Rua Sarmento Leite, $187,2^{\circ}$ andar, Porto Alegre, Rio Grande do Sul, RS, Brazil (e-mail: dudacambruzzi@yahoo.com.br).
\end{abstract}

\begin{abstract}
Introduction Angiosarcoma (AG) is a malignant mesenchymal neoplasm that predominantly affects the soft tissues and, to variable degrees, expresses the morphological and functional characteristics of the endothelium. The incidence of sarcomas of the central nervous system (CNS) is low ( $0.5 \%$ to $2.7 \%$ ), and AGs involving the brain are even rarer.

Case Description A 45-year-old male patient presented with complaints of headache, nausea, and vomiting. An examination showed bilateral papilledema and a right lung pleurotomy. The patient's previous history included drug addiction, pulmonary tuberculosis, lung abscess, pleural empyema, and pulmonary artery embolization

\section{Keywords}

- angiosarcoma

- brain sarcoma

- central nervous system

- pathology

- immunohistochemistry

- prognosis for severe hemoptysis. Computed tomography/magnetic resonance imaging scans revealed a large intra-axial lesion extending into the right parietal and temporal lobes, with hemorrhagic zones. The patient underwent surgical resection of the lesion. Microscopy showed a poorly-differentiated, high-grade malignant tumor composed of plump/epithelioid cells forming small vascular spaces and solid nests, compatible with AG.In the postoperative period, the patient developed recurrent hemoptysis. A biopsy of the tissues adjacent to the pleurotomy determined the diagnosis of pulmonary AG. At 30 days after the resection, the patient died from hemoptysis, hemothorax, lung atelectasis, and intracranial hypertension related to the recurrence of the brain tumor.
\end{abstract}

received

February 9, 2020

accepted

March 24, 2020
DOI https://doi.org/

$10.1055 / \mathrm{s}-0040-1712108$. ISSN 0103-5355.
Copyright $\odot 2020$ by Thieme Revinter

Publicações Ltda, Rio de Janeiro, Brazil
License terms

(c) $(1) \$$ 


\section{Resumo}

\section{Palavras-chave}

- angiossarcoma

- sarcoma cerebral

- sistema nervoso central

- patologia

- imuno-histoquímica

- prognóstico
Conclusion Angiosarcoma is a rare neoplasia related to short survival due to the high proliferative index, which must be considered in patients presenting hemorrhagic tumors. No specific genetic abnormalities have been described for this neoplasia.

Introdução $\mathrm{O}$ angiossarcoma (AG) é uma neoplasia mesenquimal maligna que afeta predominantemente os tecidos moles e, em graus variáveis, recapitula as características morfológicas e funcionais do endotélio. A incidência de sarcomas do sistema nervoso central (SNC) é baixa (0,5\% a 2,7\%), e os AGs envolvendo o cérebro são ainda mais raros.

Descrição do Caso Paciente masculino, 45 anos, apresentou queixa de dor de cabeça, náusea e vômitos. O exame físico mostrou papiledema bilateral e pleurostomia à direita. A história prévia incluía drogadição, tuberculose pulmonar, abscesso pulmonar, empiema pleural e embolização da artéria pulmonar por hemoptise grave. A tomografia computadorizada / ressonância magnética revelou uma grande lesão intra-axial com zonas hemorrágicas que se estendia para os lobos parietal e temporal direitos. $O$ paciente foi submetido à ressecção cirúrgica da lesão. A microscopia mostrou um tumor maligno de alto grau, pouco diferenciado, composto por células fusiformes / epitelioides, formando pequenos espaços vasculares e ninhos sólidos, compatíveis com AG. No pós-operatório, o paciente desenvolveu hemoptise recorrente. A biópsia dos tecidos adjacentes à pleurostomia determinou o diagnóstico de AG pulmonar. Após 30 dias da ressecção, o paciente faleceu por hemoptise, hemotórax, atelectasia pulmonar e hipertensão intracraniana relacionada à recorrência do tumor cerebral.

Conclusão A AG é uma neoplasia rara relacionada à curta sobrevida devido ao alto índice proliferativo, que deve ser considerada em pacientes com tumores hemorrágicos. Nenhuma anormalidade genética específica foi descrita para esta neoplasia.

\section{Introduction}

Malignant mesenchymal neoplasms of the central nervous system (CNS) are uncommon lesions that typically affect adults and occur as secondary tumors. Angiosarcomas (AGs) are aggressive supratentorial tumors that rarely affect CNS tissues. ${ }^{1-3}$ The primary tumor site can be difficult to determine when CNS AG is diagnosed with involvement of other organ systems. Brain AGs are intra-axial enhancing lesions associated with edema and mass effect. ${ }^{1,3-6}$ Upon gross examination, the tumor is typically soft and reddish, with extensive hemorrhagic areas. Microscopically, it is described as a high-grade tumor with elongated to plump cells and distinct vascular channels. Undifferentiated tumors, however, are not uncommon. ${ }^{1-3,6}$ The present study reports a case of a male patient with metastatic CNS AG and concomitant iron-deficiency anemia, tuberculosis, and pulmonary AG. We then discuss the morphological and clinical findings of this unusual neoplasm.

\section{Case Report}

A 45-year-old male patient was referred to the hospital with complaints of headache, nausea, and vomiting for 6 days. He had a previous history of drug addiction and pulmonary tuberculosis, which had been treated in the previous eight months. The pulmonary tuberculosis was complicated by a pulmonary abscess, severe hemoptysis, pleural empyema, and pulmonary hypertension. The patient underwent pulmonary artery embolization for the management of the hemoptysis in the previous two months. Upon physical examination, the patient had a regular general condition, bilateral papilledema, and a right lung pleurotomy. Iron-deficiency anemia was detected in a laboratory test and was associated with the multiple episodes of moderate to severe hemoptysis. Mycobacterium tuberculosis was previously identified in lung-biopsy material by Ziehl-Neelsen staining. Computed tomography (CT) and magnetic resonance imaging (MRI) scans revealed an intra-axial expansive lesion measuring $4.8 \mathrm{~cm}$ in largest diameter in the right parietal and temporal lobes (-Fig. 1) associated with a large hematoma, perilesional edema, and midline shift. The patient underwent surgical resection of the lesion and drainage of the hematoma that was responsible for intracranial hypertension. The surgical specimen was composed of irregular, soft, and reddish tissue fragments, the largest measuring $2.2 \mathrm{~cm}$ in diameter. The microscopic examination revealed a poorly-differentiated, high-grade malignant tumor composed of plump epithelioid cells forming small vascular spaces and solid nests (-Fig. 2). The lesion had positive immunostaining for CD34 (-Fig. 3), CD31 (-Fig. 4), Fli-1, factor VIII, and VEGFR and negative immunostaining for glial fibrillary acidic protein (GFAP), synaptophysin, neurofilament protein, CKM, actin 1A4, desmin, HHV-8, SOX-10, Anti Melan A antibody (melan-A). The diagnosis of CNS AG was thus established. In the postoperative period, the patient had new 


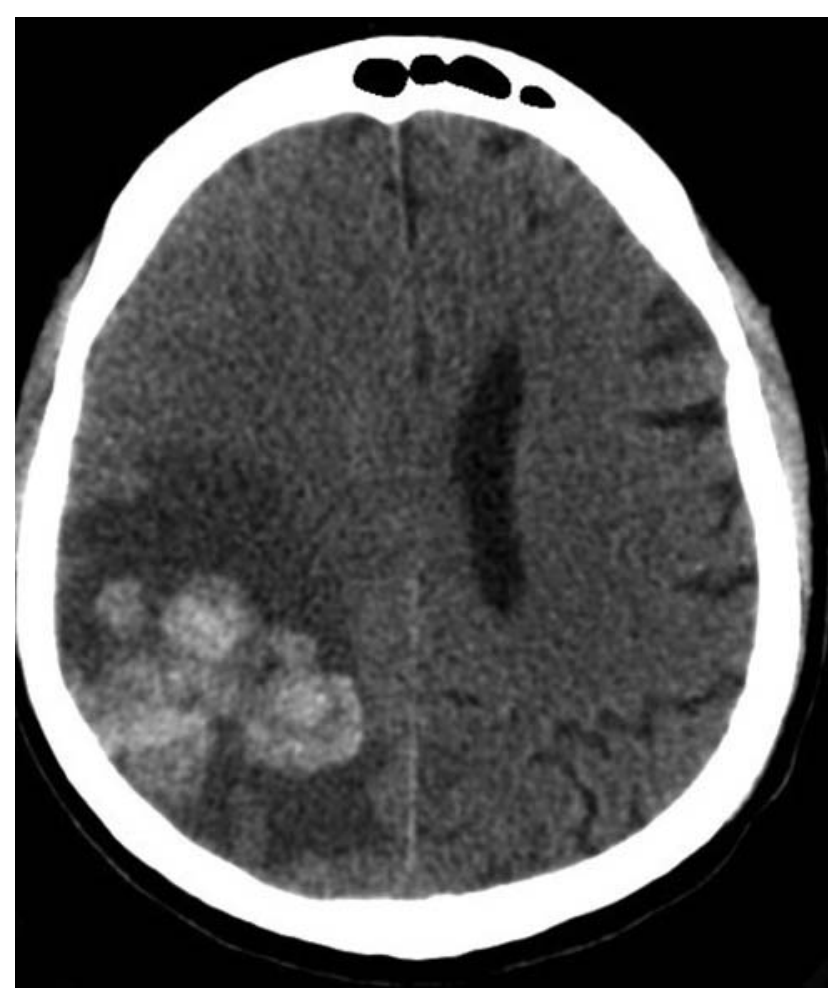

Fig. 1 Computed tomography scan showing a lesion extending into the right parietal and temporal lobes.

episodes of hemoptysis, and CT scans showed a large lesion compromising the lower lobe of the right lung(-Fig. 5), associated with hemothorax. A lung biopsy of the site of pleurotomy determined the diagnosis of AG. The patient died 30 days after brain resection from massive hemoptysis, hemothorax, right lung atelectasis, and intracranial hypertension caused by tumor relapse (-Fig. 6).

\section{Discussion}

Angiosarcoma is a malignant mesenchymal neoplasm that, to variable degrees, expresses the morphological and func-

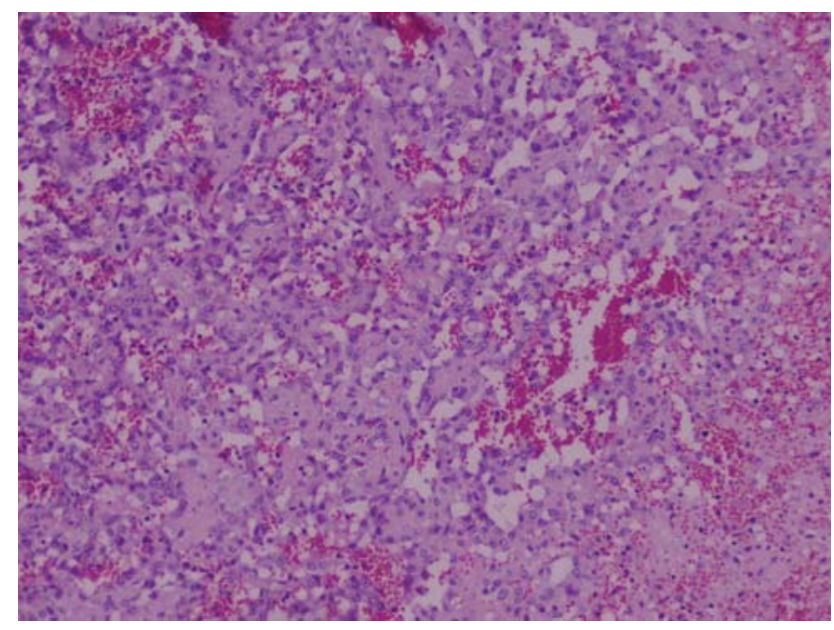

Fig. 2 Microscopy image of a poorly-differentiated, high-grade malignant tumor composed of plump epithelioid cells forming small vascular spaces. Hematoxylin-eosin, $\times 200$.

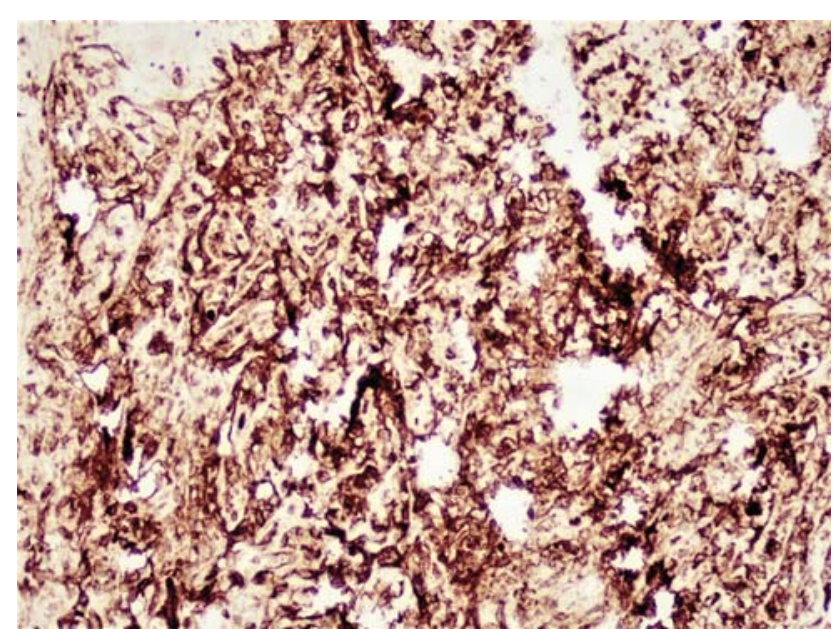

Fig. 3 Neoplastic cells showing marked immunostaining for Cluster of Differentiation 34 (CD34) (Ventana Systems), $\times 200$.

tional characteristics of the endothelium. The incidence of brain sarcomas varies from $0.5 \%$ to $2.7 \%$, and AG accounts for less than $1 \%$ of all sarcomas. The malignancy has a significant predilection for the skin ( $\sim 50 \%$ of cases) and superficial soft tissues, affecting predominantly the lower limbs. ${ }^{1,3,7-9}$ About $10 \%$ of AGs are located in deep soft tissues, whereas the remainder are found mainly in the heart, spleen, breast, kidney, and bones. Metastatic and primary CNS AGs are very rare, but can occur in children and adults. Congenital cases have also been reported. ${ }^{1-3,10-12}$ Metastatic CNS AGs are associated with intra-axial hemorrhage, and disseminate to cerebral tissues via a hematogenous route, although direct invasion of adjacent tissues can also occur. The heart is reported as the most common primary site for AG tumors metastasizing to the brain ( $75 \%$ of cases, usually originating in the atrium). ${ }^{1-3,10-12}$ Less commonprimary sites include the skin, the legs, the lungs, the pleura, the kidneys, the soft tissues, the gastrointestinal tract, the bones, and the spleen.

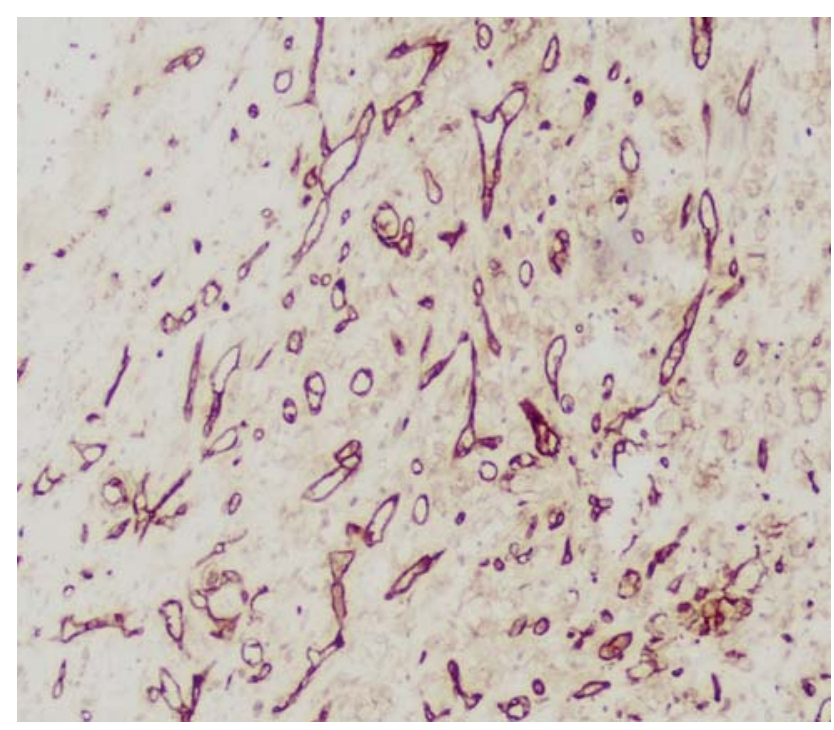

Fig. 4 Neoplastic cells showing positive immunostaining for Cluster of differentiation 31 (CD31) (Ventana Systems), ×200. 


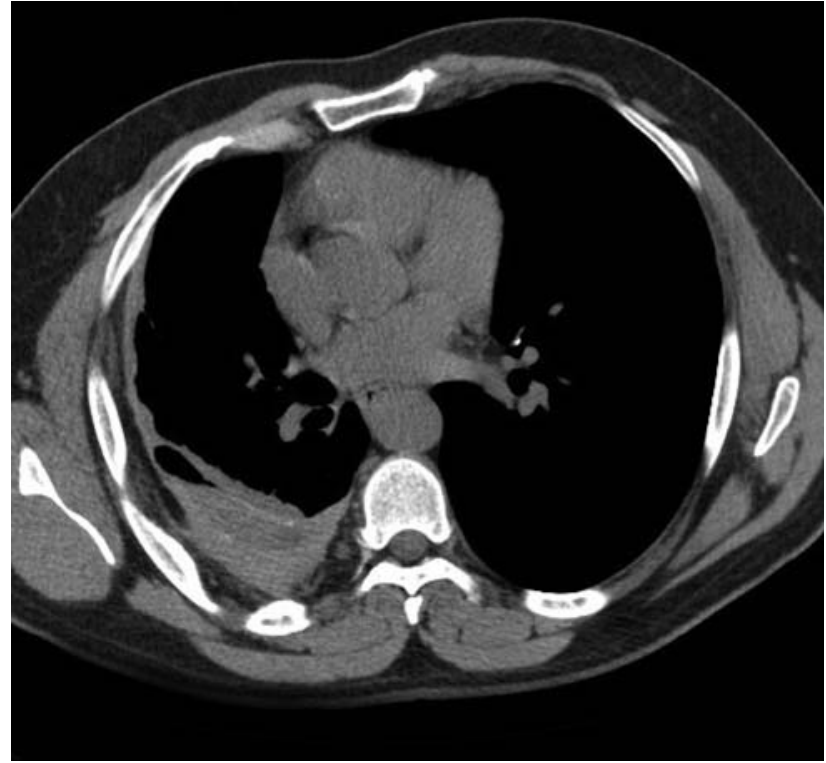

Fig. 5 Computed tomography scan showing a right hemothorax and an expansive lesion affecting the lower lobe of the right lung.

Exposure to industrial solvents, radiation, neurofibromatosis, Maffucci syndrome, Klippel-Trenaunay syndrome, and old surgical scars have been suggested as etiological factors. ${ }^{12-16}$

The most common findings of CNS AG are related to the mass effect and hemorrhagic episodes, including headache, nausea, vomiting, dizziness, seizures, hemiparesis, hemianopsia, lethargy, aphasia, and increased intracranial pressure. ${ }^{1,3,10,12-14}$ The frontal, temporal, and parietal lobes are predominantly compromised $(\sim 70 \%$ to $80 \%$ of the cases). ${ }^{1,3,10,12-14}$ The CT/MRI scans usually reveal a heterogeneous hemorrhagic lesion with variable signal intensities on T1- and T2-weighted images and adjacent areas of edema. Hydrocephalus, cystic dilation, and calcifications may be identified in large tumors by radiological examination. ${ }^{1,3,10,12-14}$ Extensive hemorrhagic lesions are frequently misdiagnosed as hematomas on CT scans. The radiological differential diagnosis of CNS AG includes other tumors with hemorrhagic foci, such as choriocarcinoma, thyroid cancer, melanoma, renal-cell carcinoma, lung carcinoma, and glioblastoma. ${ }^{1,12,14-19}$

Upon gross examination, AGs are typically multinodular hemorrhagic masses with cystic degeneration and necrosis. ${ }^{1-3,6,12,16}$ Microscopically, AGs show a wide range of morphological traits, ranging from anaplastic tumors to welldifferentiated, anastomosing vessels. Different characteristics can be observed in a single neoplasm. Solid areas are composed of high-grade epithelioid plump cells with abundant cytoplasm and large nuclei. ${ }^{1-3,6,12,16,20}$ Well-differentiated areas are characterized by distinct branched vascular channels covered by endothelial cells with mild to moderate atypia. The nuclei are usually vesicular and contain one or several small nucleoli or a prominent macronucleolus. The cytoplasm is commonly eosinophilic and often contain one or more vacuoles, which may be clear or empty, or hold intact or fragmented erythrocytes. $^{1-3,6,12,20}$ The architectural patterns include sinusoidal, ectatic, cavernous, solid, fascicular, epithelioid, and, rarely, foamy cells. The majority of AGs show a high mitotic index, marked nuclear atypia, and coagulative necrosis. In some areas, the tumor may contain a considerable amount of connective tissue interspersed between the vascular spaces. ${ }^{1-3,6,12,16,20}$ The immunohistochemical profile of neoplastic cells includes positive staining for CD34, CD31, factor VIII, The transcription factor

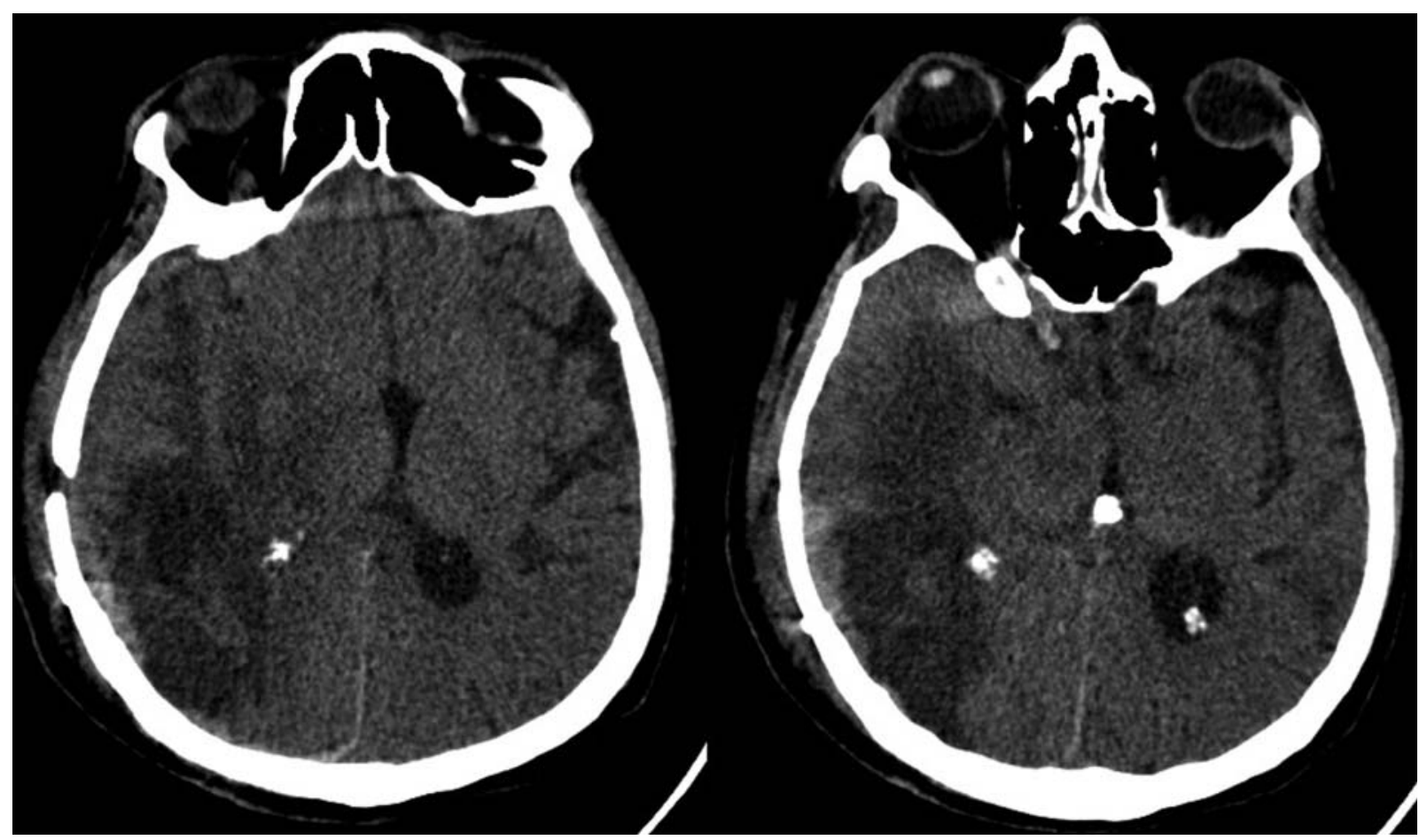

Fig. 6 Postoperative computed tomography scan showing a tumoral lesion compromising the right parietal and temporal lobes. 
Table 1 Similar cases of metastatic angiosarcoma of the central nervous system reported in the literature

\begin{tabular}{|c|c|c|c|c|c|c|}
\hline Authors & $\begin{array}{l}\text { Age/ } \\
\text { Gender }\end{array}$ & Clinicalfindings & Topography & $\begin{array}{l}\text { Primary } \\
\text { site }\end{array}$ & Treatmentmodality & Outcome \\
\hline Lin et $^{23}$ & $\begin{array}{l}63 \text { years } / \\
\text { male }\end{array}$ & Weakness in the rightarm & Left frontal lobe & Heart & Tumor resection & $\begin{array}{l}\text { Alive } 12 \text { months } \\
\text { aftersurgery }\end{array}$ \\
\hline $\begin{array}{l}\text { Zakaria } \\
\text { et al }\end{array}$ & $\begin{array}{l}45 \text { years/ } \\
\text { female }\end{array}$ & $\begin{array}{l}\text { Two-week history of confusion, } \\
\text { left hemiparesis and upper } \\
\text { motor neuron facial palsy }\end{array}$ & Multiple cerebral lesions & Heart & Radiotherapy & $\begin{array}{l}\text { Died after three } \\
\text { weeks in the hospital }\end{array}$ \\
\hline $\begin{array}{l}\text { Zakaria } \\
\text { et al }\end{array}$ & $\begin{array}{l}68 \text { years } / \\
\text { female }\end{array}$ & $\begin{array}{l}\text { Three-week history of occipital } \\
\text { headache, ataxia and weakness } \\
\text { in the left arm }\end{array}$ & $\begin{array}{l}\text { Left cerebellar, right occipital } \\
\text { and parietal periventricular } \\
\text { regions. }\end{array}$ & Heart & $\begin{array}{l}\text { Excision of the left } \\
\text { cerebellar lesion }\end{array}$ & $\begin{array}{l}\text { Died six weeks after } \\
\text { brain surgery }\end{array}$ \\
\hline $\begin{array}{l}\text { Kuratsu } \\
\text { et al }\end{array}$ & $\begin{array}{l}17 \text { years/ } \\
\text { male }\end{array}$ & $\begin{array}{l}\text { Severe headache and progressively } \\
\text { worsening visual complaint }\end{array}$ & Pineal region & Liver & Radiationtherapy & $\begin{array}{l}\text { Died twelve months } \\
\text { after brain surgery }\end{array}$ \\
\hline $\begin{array}{l}\text { Kuratsu } \\
\text { et } \mathrm{al}^{5}\end{array}$ & $\begin{array}{l}31 \text { years/ } \\
\text { female }\end{array}$ & $\begin{array}{l}\text { Severe headache and a } \\
\text { mild right hemiparesis }\end{array}$ & $\begin{array}{l}\text { Left posterior temporal lobe, } \\
\text { left thalamus, and cerebellar } \\
\text { vermis }\end{array}$ & Femur & Surgical resection & $\begin{array}{l}\text { Died sixteen months } \\
\text { after brain surgery }\end{array}$ \\
\hline $\begin{array}{l}\text { Akutsu } \\
\text { et } a^{15}\end{array}$ & $\begin{array}{l}53 \text { years/ } \\
\text { male }\end{array}$ & $\begin{array}{l}\text { Sudden onset of left-sided } \\
\text { hemifacial convulsion } \\
\text { and dysarthric speech }\end{array}$ & Right frontal lobe & $\begin{array}{l}\text { Aorta } \\
\text { artery }\end{array}$ & Surgical resection & Died after surgery \\
\hline $\begin{array}{l}\text { Vaquero } \\
\text { et } \mathrm{al}^{17}\end{array}$ & $\begin{array}{l}30 \text { years } / \\
\text { male }\end{array}$ & Headacheandvomiting & Right frontal lobe & Heart & Surgical resection & $\begin{array}{l}\text { Died sixteen months } \\
\text { after brain surgery }\end{array}$ \\
\hline $\begin{array}{l}\text { Kardes } \\
\text { et } a^{24}\end{array}$ & $\begin{array}{l}35 \text { years/ } \\
\text { male }\end{array}$ & $\begin{array}{l}\text { Decline in the level of } \\
\text { consciousness and } \\
\text { quadriparesia }\end{array}$ & Both parieto-occipitalareas & Penis & Surgical resection & $\begin{array}{l}\text { Died one month after } \\
\text { brain surgery }\end{array}$ \\
\hline $\begin{array}{l}\text { Plotnik } \\
\text { et } \mathrm{al}^{25}\end{array}$ & $\begin{array}{l}61 \text { years/ } \\
\text { female }\end{array}$ & Blurringof visual acuity & Right occipital lobe & Spleen & Surgical resection & $\begin{array}{l}\text { Lived five years } \\
\text { after splenectomy }\end{array}$ \\
\hline
\end{tabular}

erythroblastosis virus E26 transforming sequence related gene (ERG), Fli-1, and, less frequently, D2-40 and Anti-alpha smooth muscle Actin antibody (SMA). Epithelioid AG frequently exhibits positive immunostaining for CKM and EMA. Expression for HHV-8 and latency-associated nuclear antige (LANA-1) antibodies are characteristic of Kaposi sarcoma, whereas gliosarcoma with angiosarcomatous features may show positive staining for GFAP. ${ }^{6-9,11-13,21}$ The ultrastructural findings include epithelioid/plump neoplastic endothelial cells disposed in a basal lamina and showing tight junctions and surface-oriented pinocytotic vesicles. An incomplete layer of pericytes is a common ultrastructural finding of CNS AGs. ${ }^{1,2,6-8,12,13,16}$ No specific genetic abnormalities have been described for primary CNS AGs, which frequently exhibit upregulation of vascularspecific receptor tyrosine kinases, such as TIE1, KDR, FLT1, and TEK. Upregulation of VEFGR3 (FLT4) in $5 q 35$ is found in $25 \%$ of metastatic AG cases, and upregulation of MYC in $8 \mathrm{q} 24$ is a hallmark of radiation-induced AG. Mutations in vascular endothelial growth factor (VEFGR) (KDR) are observed in 10\% of AG cases. Histological differential diagnoses include epithelioid hemangioendothelioma, Kaposi sarcoma, gliosarcoma with angiosarcomatous features, metastatic carcinomas, and choriocarcinoma. $^{1,7,11,16,20-25}$ - Table 1 shows a short narrative review of metastatic CNS AG cases found in the PubMeddatabase that are comparable to the case herein reported.

Surgical resection of both primary and secondary CNS AGs with adjuvant chemotherapy is the treatment of choice. There is no significant evidence for radiotherapy. 2,3,8,10,12,13,16,18,22 The prognosis is poor, with most patients dying within six months after surgery/histological diagnosis. The factors associated with a worse prognosis include older age, large tumors, and high Cell proliferation marker $\left(\mathrm{K}_{\mathrm{i}}-67\right)$ expression. ${ }^{2,3,10,12,16,18,22}$
Angiosarcoma is a rare neoplasia related to short survival due to the high proliferative index, and it must be considered in patients presenting hemorrhagic tumors. In the present article, the authors reported a case of lung AG determining CNS metastasis and severe anemia due to frequent episodes of intractable hemoptysis. At this time, no immunohistochemical findings are able to predict the prognosis or clinical course, and no specific genetic abnormalities have been described for this neoplasia.

\section{Abbreviations and Acronyms}

CNS central nervous system

AG angiosarcoma

CT computed tomography

MRI magnetic resonance imaging

CD34 cluster of Differentiation 34

CD31 cluster of differentiation 31

Fli-1 nuclear marker of endothelial differentiation

VEGFR vascular endothelial growth factor.

GFAP glial fibrillary acidic protein

CKM anti-cytokeratins

actin $1 \mathrm{~A} 4$ anti- $\alpha$-Actin antibody

HHV-8 anti-hyman herpesvirus type 8

SOX-10 SRY-related HMG-box 10 protein

melan-A anti Melan A antibody

ERG the transcription factor erythroblastosis virus E26 transforming sequence related gene

D2-40 podoplanin

SMA anti-alpha smooth muscle actin antibody

EMA epithelial membrane antigen antibody

LANA-1 latency-associated nuclear antigen 
tyrosine kinase with immunoglobulin like and EGF like domains 1

KDR anti-KDR (Ab-1214) antibody

FLT1 fms related tyrosine kinase 1 protein

TEK anti-tyrosine-protein kinase receptor

VEFGR3 vascular endothelial growth factor receptor 3

FLT4 fms related receptor tyrosine kinase 4

MYC recombinant Anti-c-Myc antibody

Ki-67 cell proliferation marker

\section{Conflict of Interests}

The authors have none conflict of interests to declare.

\section{References}

1 Guode Z, Qi P, Hua G, Shangchen X, Hanbin W. Primary cerebellopontine angle angiosarcoma. J Clin Neurosci 2008;15(08): 942-946

2 Baldovini C, Martinoni M, Marucci G. Epithelioid angiosarcoma of the septum pellucidum. Case Rep Pathol 2013;2013:603671. Doi: $10.1155 / 2013 / 603671$

3 La Corte E, Acerbi F, Schiariti M, et al. Primary central nervous system angiosarcoma: a case report and literature review. Neuropathology 2015;35(02):184-191

4 Charman HP, Lowenstein DH, Cho KG, DeArmond SJ, Wilson CB. Primary cerebral angiosarcoma. Case report. J Neurosurg 1988;68 (05):806-810

5 Kuratsu J, Seto H, Kochi M, Itoyama Y, Uemura S, Ushio Y. Metastatic angiosarcoma of the brain. Surg Neurol 1991;35(04): 305-309

6 Mena H, Ribas JL, Enzinger FM, Parisi JE. Primary angiosarcoma of the central nervous system. Study of eight cases and review of the literature. J Neurosurg 1991;75(01):73-76

7 Folpe AL, Chand EM, Goldblum JR, Weiss SW. Expression of Fli-1, a nuclear transcription factor, distinguishes vascular neoplasms from potential mimics. Am J Surg Pathol 2001;25(08):1061-1066

8 Miettinen M, Wang ZF, Paetau A, et al. ERG transcription factor as an immunohistochemical marker for vascular endothelial tumors and prostatic carcinoma. Am J Surg Pathol 2011;35(03):432-441

9 Ritter JH, Mills SE, Nappi O, Wick MR. Angiosarcoma-like neoplasms of epithelial organs: true endothelial tumors or variants of carcinoma? Semin Diagn Pathol 1995;12(03):270-282

10 Zakaria Z, Tambirajoo K, Sattar MT, Farrell MA. Rapid clinical course of multiple metastatic cerebral angiosarcoma. Turk Neurosurg 2015;25(04):643-648
11 Berkman RA, Merrill MJ, Reinhold WC, et al. Expression of the vascular permeability factor/vascular endothelial growth factor gene in central nervous system neoplasms. J Clin Invest 1993;91 (01):153-159

12 Drosos E, Kalyvas A, Komaitis S, et al. Angiosarcoma-related cerebral metastases: a systematic review of the literature. Neurosurg Rev 2019. Doi: 10.1007/s10143-019-01127-y

13 Hackney JR, Palmer CA, Riley KO, Cure JK, Fathallah-Shaykh HM, Nabors LB. Primary central nervous system angiosarcoma: two case reports. J Med Case Reports 2012;6:251. Doi: 10.1186/17521947-6-251

14 Balamurali G, du Plessis DG, Wengoy M, Bryan N, Herwadkar A, Richardson PL. Thorotrast-induced primary cerebral angiosarcoma: case report. Neurosurgery 2009;65(01):E210-E211, discussion E211. 10.1227/01.NEU.0000348294.05571.D9

15 Akutsu H, Tsuboi K, Sakamoto N, Nose T, Honma S, Jikuya T. Cerebral metastasis from angiosarcoma of the aortic wall: case report. Surg Neurol 2004;61(01):68-71

16 Young RJ, Brown NJ, Reed MW, Hughes D, Woll PJ. Angiosarcoma. Lancet Oncol 2010;11(10):983-991

17 Vaquero J, Martínez R, Coca S, Oya S, Burgos R. Cerebral metastasis from angiosarcoma of the heart. Case report. J Neurosurg 1990;73 (04):633-635

18 Jerjir N, Lambert J, Vanwalleghem L, Casselman J. Primary angiosarcoma of the central nervous system: Case report and review of the imaging features. J Belg Soc Radiol 2016;100(01):82

19 Kirk IR, Dominguez R, Castillo M. Congenital primary cerebral angiosarcoma: CT, US, and MR findings. Pediatr Radiol 1992;22 (02):134-135

20 Suzuki Y, Yoshida YK, Shirane R, Yoshimoto T, Watanabe M, Moriya T. Congenital primary cerebral angiosarcoma. Case report. J Neurosurg 2000;92(03):466-468

21 Kurian KM, Tagkalakis P, Erridge SC, Ironside JW, Whittle IR. Primary intracranial angiosarcoma of the Pineal gland: an unusual cause of recurrent intraventricular haemorrhage and superficial haemosiderosis. Neuropathol Appl Neurobiol 2006;32(05): 557-561

22 Deyrup AT, Miettinen M, North PE, et al. Angiosarcomas arising in the viscera and soft tissue of children and young adults: a clinicopathologic study of 15 cases. Am J Surg Pathol 2009;33 (02):264-269

23 Lin CT, Ducis K, Tucker S, Tranmer B. Metastatic cardiac angiosarcoma to the lung, spine and brain: A case report and review of the literature. World Neurosurg 2017;107(1049):1049.e9-1049. e12

24 Kardes O, Aydemir F, Suner HI, et al. Brain metastasis of penile angiosarcoma. Urol J 2018;15(01):53-55

25 Plotnik AN, Schweder P, Tsui A, Kavar B. Splenic angiosarcoma metastasis to the brain. J Clin Neurosci 2008;15(08):927-929 